\title{
Svensk välfärdsforskning
}

\author{
ROBERT ERIKSON
}

\section{I artikeln behandlas svensk välfärdsforskning under hundra år. Författaren tar sin utgångspunkt i emigrations- utredningen i början av 1900-talet och följer utvecklingen fram till dagens kontinuerliga välfärdsmätningar.}

Begreppet välfärdsforskning har under senare år avsett studier av människors villkor i materiellt och socialt avseende. Med den avgränsning som här görs av välfärdsforskning avser den villkoren på individuell nivå och åtminstone i princip hela livssituationen, det vill säga att studier som endast avser exempelvis individers hälsa eller inkomster inte tas upp, även om båda förhållandena är av uppenbar betydelse för välfärden. Denna artikel är inte ett försök att ge en heltäckande bild av svensk välfärdsforskning, utan är endast ett försök att beskriva huvuddragen i den svenska ansatsen.

Ursprunget till svensk välfärdsforskning står att finna $\mathrm{i}$ utredningsväsendet och genom åren har offentliga utredningar betytt mycket för forskningsutvecklingen. Även så har denna forskning under de senaste decennierna allt mer kommit att analysera processer och mekanismer bakom människors välfärd och på det hela taget fått en svagare anknytning till politi-

Robert Erikson är huvudsekreterare i Forskningsrådet för arbetsliv och socialvetenskap (FAS) och professor i sociologi med inriktning mot levnadsnivån vid Institutet för social forskning (SOFI) ken - dock bedrevs så sent som år 2001 välfärdsforskning inom en offentlig utredning. Utredningarnas betydelse gör det emellertid rimligt att inledningsvis behandla några av dem som påverkat välfärdsforskningen. Därefter försöker jag ta upp vad jag tror har varit karakteristiskt för den svenska forskningen inom området och diskuterar avslutningsvis några möjliga utvecklingsalternativ för välfärdsforskningen. Det kan emellertid vara värt att börja vid den tid då CSA bildades, eftersom man redan då gjorde utredningar där beskrivningar och analyser skulle kunna betecknas som välfärdsforskning.

\section{Emigrationsutredningen}

Vid det förra seklets början uttrycktes en oro över »den rent ekonomiska förlusten ... förlusten av andlig kraft ... minskningen i vår försvarskraft» som emigrationen till Amerika orsakade. ${ }^{1}$ I syfte att utreda bakgrunden till den stora emigrationen från Sverige och föreslå »de ändringar i gäl-

1 Motion i riksdagen av Ernst Beckman citerad i Sundbärg 1913, sid. 6-7. 
lande lagstiftning som kunna anses vara af behofvet påkallade» (Sundbärg 1913, 39) gavs statistikern Gustav Sundbärg år 1907 i uppdrag att verkställa en statistisk-historisk utredning av emigrationsfrågan.

Slutbetänkandet om nära 900 sidor kom ut år 1913 och hade föregåtts av 20 bilagor, vilka behandlade allsköns ärenden såsom utvandringslagstiftning, bygdestatistik och bygdeundersökningar, geografiska betingelser för näringslivet, bondeklassens undergrävande, arbetsmetoder i Amerika, småbruksrörelsen i främmande länder liksom folklynnet och utvandringen. Utredningen ger en bred bild av det svenska samhället efter det förra sekelskiftet med en särskild betoning på jordbruket och den jordbrukande befolkningens villkor.

Utredningen innehåller en omfattande redovisning av demografiska uppgifter rörande antalet födda och döda från 1750 och framåt, liksom om in- och utvandring. Men den ger också läsaren en inträngande bild av näringslivet, och därmed sammanhängande utkomstmöjligheter, runt om i Sverige. Utkomstmöjligheterna inom jordbruket tas upp särskilt, vilket ter sig naturligt med tanke på att närmare hälften av befolkningen fortfarande vid tiden för emigrationsutredningen var sysselsatt i jord- och skogsbruk och att möjligheterna att förvärva jord i Amerika antogs vara en viktig förklaring till den stora utvandringen från landsbygden. ${ }^{2}$ Även om Sundbärg framhåller att en mångfald av orsaker ligger bakom emigrationen menar han att det är

2 Jämför diskussionen, som den refereras i Edebalks artikel i detta tidskriftsnummer, om hur man i valet av pensionssystem bekymrade sig om de ekonomiska problemen på landsbygden. »missförhållandena inom jordbruket, som för närvarande egentligen förklara emigrationen från vårt land" (Sundbärg 1913, 661).

Levnadsvillkoren för befolkningen på landsbygden tas upp och torparnas hårda villkor liksom statarnas usla förhållanden redovisas ingående. Medan de demografiska förhållandena och näringslivet i huvudsak beskrivs med hjälp av statistiska metoder, användes vad som kanske kan kallas kvalitativa observationsstudier för att beskriva befolkningens levnadsvillkor. De beskrivs i långa citat hämtade från olika observatörer.

Som helhet får man som läsare en som det tycks god bild av den svenska befolkningens sociala och ekonomiska förhållanden vid 1900-talets början och likaså en rimlig övergripande förklaring till den stora utvandringen.

\section{Befolkningskommissionen}

Knappt trettio år efter tillsättandet av emigrationsutredningen, år 1935, bekymrar sig återigen riksdag och regering så om befolkningsutvecklingen att den tillsätter en kommission med uppgift att utreda orsaker och föreslå åtgärder. Vid detta tillfälle är det emellertid inte utvandringen utan de låga födelsetalen - påtalade av makarna Myrdal i sin berömda bok Kris i befolkningsfrågan (1934) - som utgör grunden för oron. »Intet folk med oförsvagad livsvilja och livskraft kan inför den i vårt land nu konstaterbara utvecklingstendensen underlåta att vidtaga energiska åtgärder för att få en förändring till stånd" skrev statsrådet och chefen för Kungl. Socialdepartementet, Gustav 
Möller, när kommissionen skulle tillsättas (Befolkningskommissionen 1938a, 4) - ett uttalande som kanske kan vara värt att begrunda idag, när födelsetalen är lägre än de var när det gjordes. I Möllers direktiv till utredningen formulerar han stora delar av det socialpolitiska program, som sedan kom att genomföras under de kommande decennierna. Kommissionens direktiv gav således mycket klara anvisningar om karaktären av de förslag som den förväntades föra fram. Ordförande för kommissionen blev Nils Wohlin, som även hade arbetat för Emigrationsutredningen, men som lämnat denna på grund av meningsskiljaktigheter med Sundbärg.

Även denna utredning resulterade i ett stort antal delbetänkanden. Ett av dessa innehöll, vilket förefaller naturligt med tanke på det grundläggande problem som kommissionen hade att behandla, en djupgående analys av den demografiska utvecklingen fram till 1930-talets mitt och en befolkningsframskrivning fram till år 1985 (Befolkningskommissionen 1938b). Denna byggde på fyra olika hypoteser om giftermålsfrekvens och fruktsamhet inom och utom äktenskapet. Dessa hypoteser ledde till prognoser om en förväntad folkmängd i Sverige år 1985 från knappt 4,5 miljoner invånare enligt den mest restriktiva hypotesen till knappt 6 miljoner enligt den minst restriktiva, allt minskningar i förhållande till folkmängden år 1935 om 6,25 miljoner invånare. Den faktiska folkmängden blev år 1985 (8,4 miljoner) nästan dubbelt så stor som den enligt den mest restriktiva prognosen och ungefär en tredjedel större än enligt den mest expansiva framskrivningen. Ändå avsåg prognosen ett område där man hade goda kunskaper och den gjordes med hjälp av mycket kvalificerade modeller. Detta kan kanske illustrera hur svårt det är att uttala sig om framtiden och vara ett memento för oss när vi tror oss kunna bedöma hur samhället kommer att utvecklas. Författarna till prognosen, statistikerna Sven Wicksell och Carl-Erik Quensel, framhöll också att det var en befolkningsframskrivning snarare än en prognos, vilket kanske kan tolkas som en medvetenhet hos dem om att händelser som de omöjligen kunde förutse skulle kunna inträffa, tydligt manifesterat i uppgången i födelsetal under 1940-talet och den ökade invandringen från andra världskrigets slutskede och framgent.

På initiativ av kommissionen genomfördes i slutet av år 1935 en allmän folkräkning grundad på församlingsböckerna samt i mars 1936 en partiell räkning. Den senare undersökningen samlade in uppgifter från en femtedel av befolkningen via direkt räkning, det vill säga med hjälp av "folkräknare». Det var första gången en sådan metod användes och skälet var att de uppgifter som skulle samlas in endast svårligen eller inte alls gick att erhålla på någon annan väg. Huvudsyftet med folkräkningen var att belysa den äktenskapliga fruktsamheten och några av dess bestämningsfaktorer. För detta syfte samlade man bland annat in uppgifter om äktenskapets varaktighet, hustruns vigselålder, yrke och social ställning, inkomst, hustruns yrkesverksamhet, skol- och yrkesutbildning, yrkesväxling och bostadsförhållanden. Undersökningen år 1936 var på detta sätt en föregångare både till senare folk- och bostadsräkningar liksom till undersökningarna om befolk- 
ningens levnadsförhållanden. Folkräkningsmaterialet var långt ifrån fullständigt analyserat när kommissionen avlämnade sin slutrapport 1938.

Befolkningskommissionen var dock inte den enda utredning som hade att utreda de sociala förhållandena på 1930-talet. Redan 1933 tillsattes exempelvis den bostadssociala utredningen, som med sina förslag kom att lägga grunden för bostadspolitiken under flera decennier.

\section{Låginkomstutredningen}

År 1965, när trettio år gått efter inrättandet av befolkningskommissionen, tillsatte regeringen en utredning som bland annat hade till uppgift att "överväga vilken information som krävs för att ge låginkomstdiskussionen ett godtagbart underlagu. ${ }^{3}$ Utredningen, som kom att benämnas Låginkomstutredningen, var en enmansutredning med Rudolf Meidner som utredningsman efter två inledande första år då Ingvar Svennilsson hade detta uppdrag. Per Holmberg var en aktiv och så småningom kontroversiell huvudsekreterare. Utredningen planerade att inför sitt slutbetänkande ge ut tre underlagsrapporter- om det svenska folkets inkomster, köpkraft och levnadsnivå. De två första kom ut under 1970 och 1971, men den tredje blev aldrig publicerad liksom inte heller något slutbetänkande, då utredningen lades ner den 1 oktober 1971 utan att någon av de senare två rapporterna blivit skrivna och än mindre utgivna. ${ }^{4}$ Trots

3 Direktiven till utredningen återfinns i SOU 1970:34, sid. 9-11.

4 En redogörelse för arbetet i utredningen och att endast ett fåtal betänkanden publicerades av utredningen skrevs ett stort antal rapporter inom utredningens ram, eftersom femton sådana, författade av dem som arbetade med levnadsnivåundersökningen, lämnades över till utredningen eller till den efterföljande arbetsgruppen.

Direktivens fråga om vilken information som erfordras för att ge låginkomstdiskussionen ett godtagbart underlag kan kanske sägas utgöra grundstenen för den moderna svenska välfärdsforskningen, eftersom utredningsmannen valde att tolka direktiven så att han bland annat lät en grupp sociologer, med Sten Johansson i spetsen, genomföra en undersökning av det svenska folkets levnadsvillkor - av vad som skulle komma att beskrivas som levnadsnivån $\mathrm{i}$ Sverige. Levnadsnivåundersökningen var i allt väsentligt Johanssons verk. Därmed gav han ett unikt svenskt bidrag till den

en sammanfattning av resultaten från de undersökningar som den initierade finns i den i samband med utredningens nedläggning bildade Arbetsgruppens för låginkomstfrågor Kompendium om Låginkomstutredningen, DS IN 1971:16. Det formella skälet till att utredningen lades ner var att Rudolf Meidner lämnade uppdraget som utredningsman. Att någon ny utredningsman inte utsågs torde dock ha sammanhängt med att delar av regeringen, och då särskilt finansminister Gunnar Sträng, inte kunde fördra Per Holmbergs agerande som huvudsekreterare (ett misshag som nog delades av arbetsmarknadens parter) utan föredrog att det fortsatta arbetet skedde i en interdepartemental arbetsgrupp inom regeringskansliet. Samtliga som skrev underlagsrapporter till utredningen fick dock möjlighet att fullfölja detta arbete och Per Holmberg gavs utrymme att skriva ett betänkande om hur låginkomstutredningens arbete skulle fortsättas. 
internationella samhällsvetenskapen. Levnadsnivåundersökningen innebar också inledningen av vad som kommit att betecknas välfärdsforskning, varför den förtjänar att behandlas närmare här. ${ }^{5}$

\section{Levnadsnivåundersökningen}

Den första levnadsnivåundersökningen genomfördes år 1968 som intervjuer med ett representativt urval om cirka 6000 personer i åldrarna 15 till 75 år, bosatta $i$ Sverige. Mer än tio år dessförinnan hade man inom FN:s ram diskuterat levnadsnivå (level of living) som ett begrepp med vilket det skulle vara möjligt att bättre än med hjälp av bruttonationalprodukten beskriva välfärdens nivå i de olika medlemsnationerna. Under den senare delen av 1960talet fördes en diskussion av hur utvecklingen $i$ en nation skall beskrivas i socialt avseende och de första systematiska försöken till en sådan beskrivning genomfördes också (Se Bauer 1966; U.S. Department of Health, Education and Welfare 1969 eller Central Statistical Office 1970). Det fanns således en internationell diskussion av de frågor som låginkomstutredningen hade att ta ställning till, men genom levnadsnivåundersökningen och den forskning som följde på den kom Sten Johansson att ge ett självständigt och originellt bidrag till denna diskussion.

Sedan länge hade man sett problemen med att använda administrativa uppgifter

5 Den här givna beskrivningen av Levnadsnivåundersökningen bygger till delar på en tidigare uppsats: „Den svenska levnadsnivåforskningen", publicerad i Björklund and Mäler (1991). Se också Erikson och Uusitalo (1987) från den sociala sektorn - t. ex. antal sjukhusdagar eller läkarbesök per invånare - till att beskriva tillstånd och utveckling inom ett land. I levnadsnivåundersökningen utnyttjade Johansson en ansats, som tidigare främst använts för opinionsundersökningar och attitydmätning, surveytekniken, till att försöka ge en helhetsbild av människors levnadsförhållanden. Att i en och samma undersökning försöka beskriva människors hälsa, arbetsförhållanden, ekonomiska resurser, bostadsförhållanden, familjeförhållanden etc. var aldrig förut prövat och det var långt ifrån klart att det skulle vara möjligt. Det hävdades till exempel att en rättvisande mätning av människors hälsa inte kunde utföras av andra än sjukvårdsutbildad personal.

Den teoretiska grunden för levnadsnivåbegreppet - förfogande över resurser - hämtades från den engelske samhällsforskaren Richard Titmuss, men var även i en mer inskränkt mening välkänd inom den nationalekonomiska diskussionen av människors välfärd. Johansson definierade levnadsnivå som »förfogande över resurser i pengar, ägodelar, kunskaper, psykisk och fysisk energi, sociala relationer, säkerhet m. m. med vars hjälp individen kan kontrollera och medvetet styra sitt liv" (Johansson 1970, s. 25). Definitionen markerar människan som subjekt, som handlande aktör, snarare än som passiv konsument av varor och tjänster, samtidigt som "det goda livet" förblir odefinierat - var och en får själv bestämma vad det innebär och använda sina resurser för att söka uppnå det.

Mätningen av människors levnadsnivå kom emellertid mer att påverkas av det tidigare nämnda arbetet inom FN och av över- 
väganden närmast av sunt förnuftskaraktär än av den rätt abstrakta definitionen. I praktiken kom nämligen levnadsnivå att definieras av människors läge på nio olika komponenter, av vilka några endast med viss svårighet kan betraktas som resurser - ett par av komponenterna avser snarare individernas omedelbara levnadsvillkor. De nio komponenterna var ursprungligen (Johansson 1970, sid 32-36):

Hälsa

Kostvanor

Bostad

Uppväxtförhållanden och familjerelationer

Utbildning

Sysselsättning och arbetsplatsförhållanden

Ekonomiska resurser

Politiska resurser ${ }^{6}$

Fritid och rekreation.

Komponentlistans något tillfälliga karaktär visas av att den ändrats över åren, både vad avser innehåll och beteckningar. Den största förändringen är att kostvanor har tagits bort som en enskild komponent - de ses nu snarast som en del av orsaken till

6 Politiska resurser är kanske den enda komponenten av de nio vars innebörd inte uppenbart följer av namnet. Om ekonomiska resurser är de medel vi kan använda för att uppnå våra mål på marknaden är politiska resurser de medel som kan användas i politiken. De viktigaste bedömdes vara rösträtten, möjligheten att bilda och ansluta sig till politiska och fackliga organisationer, möjligheten att ta kontakt med ansvariga politiker och myndigheter. Det som främst mättes var i vilken utsträckning individerna hade utnyttjat dessa rättigheter. hälsovariationer i befolkningen - medan "säkerhet till liv och egendom» kommit till. Samtidigt som således komponentlistan i viss mån är godtycklig till sitt exakta innehåll och till hur komponenterna betecknas är den som helhet långt ifrån skönsmässig. Som Johansson (1979) påpekat är liknande komponentlistor, vilka upprättats för ungefär samma syfte men i olika länder och under olika politiska system, förvånansvärt lika. Även om detta delvis kan antas bero på ömsesidig påverkan, man har helt enkelt studerat hur andra har gjort, måste det rimligtvis också kunna återföras på att överväganden om vilka de centrala aspekterna av människors levnadsvillkor är leder till ungefär samma slutsatser, åtminstone om de utförs inom ramen för offentlig statistikproduktion eller utredningsverksamhet $\mathrm{i}$ industriländerna.

Att komponenterna inte härletts ur resursdefinitionen beror säkert främst på att det inte är möjligt att göra på ett någorlunda strikt sätt utifrån samhällsvetenskaplig teoribildning. Till en del tyder det emellertid också på att resursdefinitionen kan vara otillräcklig. Resurser har nämligen inte ett värde oberoende av det omgivande samhället, oberoende av de arenor på vilka de skall användas, för att använda det begrepp den norska Levekårsundersøkelsen (NOU 1976, 28) hämtade från den amerikanske sociologen James Coleman (1971). Om arenorna inte är desamma kan en jämförelse av individernas resurser ge en missvisande bild av deras respektive förhållanden eller, för att anknyta till definitionen av levnadsnivå, av deras möjligheter att styra sina liv. I den situationen kan de realiserade valen, de faktiska villkor under vilka människor lever, 
vara mer rättvisande, vilket kan motivera komponentlistans något blandade karaktär. Amartya Sen har i sin diskussion av välbefinnandets filosofiska grundvalar gett en teoretisk formulering av mänsklig välfärds centrala element som ligger mycket nära levnadsnivåundersökningens praktik (Sen 1984; 1985).

\section{Fortsatta undersökningar}

Diskussionen av låginkomstutredningen, levnadsnivåundersökningen och om hur befolkningens ekonomiska och sociala förhållanden bäst skulle beskrivas fortsatte även efter det att utredningen lagts ned. Riksdagen 1973/74 tog beslut om hur arbetet skulle fortsätta. Det då nystartade Institutet för social forskning (SOFI) fick i uppdrag att försöka konkretisera idén om en löpande social rapportering, medan Statistiska Centralbyrån (SCB) fick uppgiften att fortlöpande redovisa tillståndet i befolkningen. I anslutning till dessa uppdrag gavs bägge institutionerna medel att genomföra empiriska undersökningar. SOFI valde att redan år 1974 följa upp 1968 års levnadsnivåundersökning, genom att med hjälp av i stort sett samma frågeformulär återintervjua dem som deltagit i 1968 års undersökning samt tilläggsurval av ungdomar och invandrare. Därutöver kunde uppgifter om de intervjuades inkomster från 1951 och framåt inhämtas i SCB:s register. Nya intervjuer med överlevande och kvarboende personer samt med nya grupper av ungdomar och invandrare genomfördes sedan 1981, 1991 samt nu senast år 2000. SCB startade årliga undersökningar av levnadsförhållanden (vilka sedermera något tautologiskt kommit att betecknas som ULF-undersökningarna). En första undersökning gjordes 1974, men de första intervjuer som sedermera analyserats och rapporterats genomfördes år 1975 och intervjuer har sedan gjorts årligen. SCB:s ansats är i grunden lik levnadsnivåundersökningens, men man har arbetat med ett något större antal komponenter, varvid man under enskilda år koncentrerat studien till att särskilt avse några av dem, medan endast vissa basindikatorer redovisas för de övriga komponenterna. För ULF valde man emellertid inte, som för levnadsnivåundersökningen, en panelansats - d.v.s. att intervjua samma personer vid flera tillfällen. ${ }^{7}$ Medan den som analyserar uppgifter från LNU har möjlighet att följa enskilda individer under en följd av år, kan den som analyserar ULF-data studera förhållandena även i relativt små grupper, eftersom de årliga intervjuerna inneburit att man efterhand kommit att intervjua ett mycket stort antal individer. ${ }^{8}$

\section{Bokslutskommittén}

Drygt trettio år efter att Låginkomstutredningen tillsattes önskade regeringen för "vägledning av socialpolitiken vid

7 Det finns dock ett panelelement i ULF. Man valde, av vad jag förstår ursprungligen i syfte att reducera fältarbetskostnaderna, att efter ett antal år återvända till personer som tidigare intervjuats. $\mathrm{Nu}$ ger dock dessa återintervjuer möjlighet att bedriva en viss panelanalys.

8 Att sammanställa uppgifter från många års intervjuer för att studera villkoren i en liten grupp förutsätter, för att vara meningsfullt, att man antar att villkoren inte förändrats nämnvärt under perioden. 
ingången av nästa årtusende ... att förbättra kunskapsunderlaget för välfärdsutvecklingen.. ${ }^{9} \quad$ Bland annat för att få en bättre kunskap om de sämst ställdas situation uppdrog därför regeringen åt en kommitté att utreda välfärdsutvecklingen under 1990-talet - att göra ett bokslut över perioden. Liksom 1965 är det inte heller vid detta tillfälle den demografiska utvecklingen som är huvudorsaken bakom statsmakternas kunskapstörst, även om den ökande andelen äldre i befolkningen framstår som ett hot mot nivåerna i välfärdspolitiken. Joakim Palme utsågs till ordförande och flera av ledamöterna i kommittén hade arbetat med levnadsnivåundersökningen.

Bokslutskommittén fogade in sig i den klassiska svenska utredningstraditionen genom att till regeringen överlämna ett stort antal rapporter med väl underbyggda beskrivningar och analyser av välfärdsutvecklingen under 1990-talet. Kommitténs ledamöter stod själva för ett stort antal uppsatser, men dessutom engagerades ett flertal forskare att skriva om utvecklingen under 1990-talet inom sina respektive specialområden.

Arbetet i utredningen kan i mycket ses som en direkt fortsättning av den tidigare välfärdsforskningen i Sverige, eftersom huvuddelen av det empiriska underlaget för arbetet kom från SCB:s ULF-undersökningar och från SOFI:s levnadsnivåundersökningar. Bland annat tidigarelades uppföljningen av levnadsnivåundersökningen med ett år för att resultaten skulle kunna bli tillgängliga för kommittén.

9 SOU 2001:79, s. 277.
Levnadsnivåundersökningen 2000 genomfördes på samma sätt som de tidigare, det vill säga att man intervjuade i Sverige kvarboende personer under 76 år som tagits ut till intervjuer 1991 eller tidigare, samt urval av ungdomar och nytillkomna invandrare. Liksom 1991 gjorde man också intervjuer med bland andra personalcheferna vid företag där någon intervjuad var anställd och även de över 75 år följdes upp. ${ }^{10}$ En innovation i levnadsnivåundersökningen 2000 var att man samlade in uppgifter från barn och ungdomar i åldrarna 10-18 år, vilka bodde i hushåll där någon av de vuxna medlemmarna skulle intervjuas. ${ }^{11}$

Bokslutskommittén arbetade vidare med den ansats till studiet av välfärden som utvecklats inom levnadsnivåprojektet, men den utvecklade densamma genom att lägga större vikt vid studiet av samhälleliga institutioner som omsorg, skola, sjukvård, socialförsäkringar och arbetsmarknadsåtgärder. Det innebar att kommittén studerade de enskilda individernas resurser med avseende på de komponenter som levnadsnivåundersökningen tagit upp, men också hur vad den kallade de välfärdsstatliga institutionerna - välfärdstjänster och försörjningssystem - fungerade.

Kommittén framhåller att vi vet förvånansvärt litet om välfärdstjänsternas faktiska värde för medborgarna, om "medborgarnas möte med välfärdsstaten"

10 Intervjuerna med äldre personer genomfördes under år 2002.

11 Formuläret och analyser av svaren återfinns i Jonsson m.fl. 2001. 
(Fritzell och Lundberg 2000,15; se också SOU 2001:79). Det vill säga att det har gjorts många studier av transfereringarnas betydelse, men avsevärt färre av hur medborgarna utnyttjar välfärdstjänster av skilda slag.

Ett bättre grepp om värdet av välfärdstjänsterna är särskilt viktigt i ett jämförande perspektiv, vare sig det avser jämförelser över tid eller mellan länder. Huruvida exempelvis sjuk- och hälsovård finansieras via skatter eller genom privata försäkringar påverkar rimligtvis tolkningen av en viss spridning i fördelningen över disponibel inkomst, eftersom avgifterna i det förra systemet redan är avlagda i form av skatter, medan de i det andra måste dras från inkomsten efter skatt. Det betyder att i en jämförelse mellan två olika system borde man kanske för respektive system lägga en beräknad försäkringspremie till inkomsterna för alla som har rätt till subventionerad sjukvård. På ett liknande sätt kan man behöva ta hänsyn till värdet av andra välfärdstjänster vid jämförelser mellan länder.

I mycket förefaller kunskapen om välfärdstjänsterna i stort lida av de problem som den om välfärden gjorde på 1960-talet, det vill säga att vi vet rätt mycket om utbud och kostnader, men litet om tjänsternas värde. För exempelvis barnomsorgen kan kvaliteten beräknas som antalet barn per anställd, men den centrala kvalitetsfrågan är rimligtvis hur barnen har det eller, för att uttrycka det som Bergqvist och Nyberg "Vad barnen tycker vet vi inte mycket om" (2001, 262). Vill man följa den svenska välfärdsforskningens ansats blir emellertid inte frågan så mycket vad barnen tycker utan vilka barnens villkor i olika avseenden är.

\section{Karakteristika för svensk välfärdsforskning}

Vad var det då som karakteriserade levnadsnivåundersökningen och dess efterföljare?

\section{Brett upplagda kvantitativa studier}

Den första levnadsnivåundersökningen var, som nämnts, en intervjustudie där cirka 6000 personer i åldrarna 15 till 75 år skulle svara på frågor om sina förhållanden inom olika livsområden. Intervjuerna var av så kallat strukturerat slag, det vill säga att intervjuarna skulle läsa upp i förväg formulerade frågor och svaren på de allra flesta av dessa kodades i ett antal fasta alternativ. Denna undersökningsuppläggning kanske inte tycks så märklig idag, men enligt min uppfattning var just den empiriska ansatsen innovativ. Surveytekniken hade utvecklats i USA efter det andra världskriget och användes främst för att mäta människors uppfattningar och attityder - även om liknande ansatser tillämpats tidigare, som för den partiella svenska folkräkningen 1936. Det kunde gälla om man kunde tänka sig att rösta på demokrater eller republikaner eller vilken status man tillskrev utövare av olika yrken. En av de första större undersökningarna av detta slag som genomförts i Sverige var Torgny Segerstedts och Agne Lundquists undersökning år 1949 av människors uppfattningar om arbete och samhällsliv i två svenska industriorter (Segerstedt och Lundqvist 1952; 1955; se även Åberg 1990), medan det svenska Gallupinstitutet 
redan från 1942 ställde frågor om väljarnas politiska attityder (se Holmberg och Gilljam 1987). I arbetskraftsundersökningarna hade man i början av 1960-talet börjat använda tekniken för att få en bild av en aspekt av människors livssituation, men att försöka ge en heltäckande bild hade aldrig förut prövats. Det alternativa angreppssätt, som då var mest aktuellt, var att använda uppgifter från den officiella statistiken till att finna indikatorer på människors förhållanden och på tillståndet i riket. Ett annat alternativ, som delvis utvecklats i opposition till levnadsnivåundersökningarna, är en mer kulturantropologisk ansats varigenom man kan ge en kvalitativ bild av ett fåtal människors situation (se t.ex. Gullestad 1984 eller Björnberg och Bäck-Wiklund 1987), en ansats som dock inte kan ge en rättvisande bild av tillstånd och utveckling i ett större aggregat som en nation.

Den första levnadsnivåundersökningen har fått en rad efterföljare, både i Sverige och i de övriga nordiska länderna. Utöver de fortsatta levnadsnivåstudierna vid SOFI och ULF-undersökningarna vid SCB, har man även i de övriga nordiska länderna genomfört undersökningar som har utformats på grundval av erfarenheterna från de svenska levnadsnivåundersökningarna. $^{12}$

12 Se bland annat NOU 1976:28, Nordiska Rådet (1983), och Hansen (1986). I Norge har sedermera Statistisk sentralbyrå genomfört ett stort antal levekårsundersøkelser och FAFO (en forskningsstiftelse ursprungligen grundad av Landsorganisasjonen i Norge) har spritt konceptet till bland andra länderna i Baltikum.

\section{Levnadsvillkor eller subjektivt välbefinnande?}

En av de frågor som klarast skiljer olika ansatser för välfärdsanalys och välfärdsmätning från varandra är om analysen i första hand skall inriktas mot individernas levnadsvillkor, det vill säga de omständigheter de lever under, eller mot deras tillfredsställelse med sin situation. I Europa har man i huvudsak riktat insatserna mot de faktiska omständigheterna, medan man i U.S.A. främst har studerat människors tillfredsställelse eller lycka. ${ }^{13}$ Det val man gör i detta avseende måste förväntas påverka de resultat och slutsatser som följer, eftersom det har visat sig att sambandet mellan faktiska villkor och tillfredsställelsen med dessa villkor är ganska lågt. I tvärsnittsundersökningar tenderar man således att få ett rätt lågt positivt samband mellan levnadsvillkor och tillfredsställelse (se Allardt 1975 eller Campbell m.fl 1976). På aggregerad nivå är det tveksamt om man får något samband alls - man bör till exempel inte vänta sig att människor i genomsnitt blir mer tillfredsställda för att levnadsstandarden stiger och inte heller kan vi vänta oss att den genomsnittliga tillfredsställelsen med levnadsstandarden i olika länder ordnas efter bruttonationalprodukten per capita (se Inglehart och Rabier 1986). Orsaken till denna brist på samband mellan objektiva villkor och subjektivt välbefinnande synes

13 Den europeiska huvudinriktningen representeras väl av Zapf (1977) eller av de rapporter av typen Social Trends, som i stort sett alla de västeuropeiska statistikkontoren ger ut. För U.S.A. kan t.ex. Andrews (1986) stå som exempel på huvudinriktningen. 
vara att människors tillfredsställelse med sina levnadsvillkor inte så mycket bestäms av villkoren i sig utan mer av förhållandet mellan dem och individernas förväntningar och aspirationer. Eftersom de senare i det långa loppet tenderar att anpassas till de faktiska omständigheterna blir sambandet ganska lågt eller, på aggregerad nivå, närmast obefintligt.

Om välfärdsforskningen grundas i ett rent kunskapsintresse kan valet att studera omständigheter eller tillfredsställelse knappast ges någon annan motivering än att man finner det ena mer värt att studera än det andra. Försök har, inte oväntat, gjorts att samtidigt studera både levnadsomständigheter och tillfredsställelsen med dessa (se för ett tidigt exempel Glatzer och Zapf 1984), men resultaten har knappast gett anledning att gå vidare på denna väg. Eventuellt kan detta kanske bero på att psykologiska tillstånd främst har psykologiska determinanter och faktiska tillstånd mest faktiska determinanter, det vill säga att kopplingen är även i kausal mening svag. Om emellertid forskningen utöver det rena kunskapsintresset motiveras av ett behov av underlag för politiskt beslutsfattande, kan valet av ansats ges en fastare motivering. Efter den ovan citerade meningen ur direktiven till låginkomstutredningen fortsatte inrikesministern: "En kartläggning bör enligt min mening utföras så att den kan läggas till grund för konkreta åtgärder i syfte att förbättra låginkomstgruppernas villkor" (SOU 1970:34, 10). Även om de flesta bland de forskare som arbetat med levnadsnivåmaterialen nog funnit det mest intressant att studera människors faktiska villkor finns här i ursprunget till under- sökningarna en ytterligare motivering för en sådan inriktning. Statlig planering bör inte inriktas mot att direkt påverka människors verklighetsuppfattning - många av de futuristiska mardrömmar som presenterats oss i litteraturen har byggt på antagandet att makten direkt påverkar människors medvetanden - och direktiven framhåller också följdriktigt en förbättring av människors villkor som det önskvärda planeringsmålet. När välfärdsforskningen efterhand blivit blivit allt mer driven av ett kunskapsintresse och allt mindre av ett krav att utgöra underlag för statlig planering har emellertid, inte oväntat, frågor om subjektiv tillfredsställelse ställts till dem som intervjuats.

\section{Ett sammanfattande välfärdsmått?}

En naturlig strävan i välfärdsforskningen är att konstruera ett sammanfattande välfärdsmått med vars hjälp det vore möjligt att $i$ ett tal beskriva en individs läge i en välfärdsfördelning och därmed också den genomsnittliga välfärden i en nation eller i exempelvis olika samhällsklasser eller regioner. Det har till och med hävdats att hela verksamheten är meningslös om man inte kan konstruera ett sådant mått. I den svenska välfärdsforskningen har emellertid en sådan strävan hittills på det hela taget avvisats. Skälet är att de olika levnadsnivåkomponenterna inte är jämförbara och att det inte finns något sätt att väga samman olika komponenter som inte förutsätter en subjektiv värdering av deras relativa betydelse. Det finns, till exempel, inte någon möjlighet att avgöra vilken av två personer 
som har den högre levnadsnivån om den ena har bättre hälsa men sämre ekonomi än den andra.

Det bör dock observeras att man ändå, på vad som kan sägas vara en lägre nivå, har vägt samman ojämförbara storheter t.ex. skilda former av ohälsa eller olika slag av belastning $\mathrm{i}$ arbetet, det vill säga att det $\mathrm{i}$ beskrivningen av välfärden $i$ en nation trots allt är svårt att strikt upprätthålla principen att inte väga samman ojämförbara storheter.

Vi kan vidare knappast hävda att människor har möjlighet att välja mellan olika kombinationer av levnadsnivåkomponenterna och därmed har kunnat välja den kombination som enligt deras värderingar ger dem det största välbefinnandet. I ekonomisk teori gör man det rimliga antagandet att en persons välbefinnande är större i en situation A än i en annan situation B om personen väljer $A$ framför $B$. När man lämnar den rena varukonsumtionen blir emellertid valen allt mer hypotetiska, det vill säga att föreställningen att individerna har valt den uppsättning värden de har på olika levnadsnivåkomponenter framstår som närmast orimlig. I vissa situationer kan individerna sägas välja mellan skilda värden, exempelvis hälsa och ekonomiska resurser, men hälsoriskerna $\mathrm{i}$ arbetet har $\mathrm{i}$ många fall varit alltför litet kända och alltför underskattade för att människor skall kunna sägas ha haft ett reellt val mellan de två värdena.

\section{Ojämlikhet eller fattigdom?}

Om således den svenska levnadsnivåforskningens inriktning mot faktiska omstän- digheter kan sägas ha svarat mot andan i direktiven till låginkomstutredningen är det knappast fallet vad gäller tendensen att snarare studera ojämlikhet än fattigdom. Visserligen finns i direktiven anvisningar om att inte enbart (min emfas) koncentrera intresset till låginkomsttagarna, men om levnadsnivåundersökningen som främsta resultat hade presenterat en studie av fattigdomen i Sverige hade det varit väl förenligt med utredningsdirektiven. En sådan inriktning hade också tett sig naturlig med tanke på att fattigdomsforskningen under slutet av 1960-talet blommade upp i U.S.A. i anslutning till president Johnsons krig mot fattigdomen.

I arbetet inom Låginkomstutredningen skrev Lars Söderström ett betänkande om Den svenska köpkraftsfördelningen (SOU 1971:39). Inom Levnadsnivåundersökningen skrev Lars Sundbom en rapport om De extremt lågavlönade, alltså inte direkt om fattigdom så dock om en huvudorsak till fattigdom. Efter denna rapport har dock studiet av inkomstskillnader över hela inkomstfördelningen, snarare än en uppdelning av befolkningen i de fattiga och de övriga, på det hela taget varit dominerande inom svensk välfärdsforskning. ${ }^{14}$

I Europa var, när välfärdsforskningen utvecklades i Sverige, förgrundsgestalten inom fattigdomsforskningen engelsmannen Peter Townsend, som genomförde en stor undersökning av fattigdom i Storbritannien (Townsend 1979). Han hävdade med eftertryck att fattigdom endast kan förstås som relativ deprivation, att fattig-

14 Se dock Gustafsson (1984) eller Halleröd (1991; 1999). 
domsgränsen måste dras i förhållande till levnadsstandarden i det enskilda landet, inte i förhållande till någon absolut konsumtionsnivå. Denna betoning av fattigdom som ett relativt begrepp har skett i kontrast både till en äldre brittisk tradition (se t.ex. Rowntree 1901) och till den officiella amerikanska fattigdomsdefinitionen. Den senare definierar fattigdom som att inte kunna upprätthålla en viss minimal konsumtion, bland annat bestämd utifrån ett nödvändigt näringsintag (Orshansky 1969). Förhållandet mellan absoluta och relativa definitioner av fattigdom är långt ifrån enkelt. Amartya Sen (1992) har framhållit att en viss inkomstnivå kan innebära en mer påtaglig fattigdom, absolut sett, i ett rikare land jämfört med ett fattigare, eftersom kraven på exempelvis en "anständig" klädsel är större och på grund av att det $\mathrm{i}$ det rikare landet kan krävas större resurser för att kunna deltaga i samhällslivet på lika villkor med andra. Dock framhåller han att det också finns ett absolut element i fattigdom, som gör att en definition som resulterade i en större fattigdom i Storbritannien än i Indien vore absurd.

Oberoende av vilken fattigdomsdefinition man väljer kommer de fattiga att utgöras av dem som har inkomster under någon viss ganska godtyckligt fastställd gräns. Det har gjorts försök att bestämma fattigdom vidare än enbart med hjälp av inkomst (Mack och Lansley 1985; Ringen 1987; Halleröd 1994), men även så blir uppdelningen av fattiga och icke-fattiga bestämd enligt en relativt godtyckligt vald skiljelinje. Många har strävat efter att finna den "sanna" fattigdomsgränsen, varvid man, enligt min uppfattning förgäves, för- sökt att undvika godtycklighet genom att ge fattigdomsgränsen någon form av teoretisk förankring. ${ }^{15}$

För att uppdelningen av inkomstfördelningen, eller fördelningen av "nödvändigheter« hos Mack och Lansley, i två grupper inte skall vara helt godtycklig krävs att det sker en språngvis förändring av levnadsvillkoren vid fattigdomsgränsen, att skillnaden mellan att vara under den och över den är kvalitativ och inte bara kvantitativ. Townsend har hävdat att det föreligger en sådan kvalitativ skillnad, men har aldrig lyckats presentera några hållbara empiriska belägg för att så är fallet. Jag tror inte heller att han eller någon annan någonsin kommer lyckas därmed. Olika levnadsförhållanden och beteenden är förvisso relaterade till inkomstnivån och det finns ingen anledning att vänta sig linjära relationer, men att många skilda förhållanden skulle förändras språngvis vid en viss inkomst förefaller utomordentligt osannolikt. Problemet illustreras av floran av fattigdomsdefinitioner och också av att man även vid en viss definition inte kunnat nöja sig med att redovisa andelen under fattigdomsstrecket utan även till exempel fattigdomsgapet, det vill säga hur mycket under strecket de fattigas inkomster i genomsnitt ligger - ett mått som antyder de problem och den informationsförlust som följer av att dela upp en kontinuerlig variabel som inkomst i två kategorier.

Det finns således flera goda skäl till att välja att studera ojämlikhet snarare än fattigdom. Om man önskar att särskilt stu-

15 Se utöver de redan anförda arbetena t.ex. van Praag (1968). 
dera inkomstskillnader bland låginkomsttagarna, kan man välja spridningsmått som är speciellt känsliga för variationer i denna del av fördelningen (se Atkinson 1983 och Fritzell 1991 för tillämpningar på svenska data).

\section{Onda förhållanden}

Huruvida man bör redovisa andelen fattiga eller något mått på spridningen i inkomstfördelningen är en fråga om valet av ett globalt mått, alltså en beskrivning av situationen i aggregat som nationer eller regioner. I redovisningen av motsvarande individuella mått finns det en tendens $\mathrm{i}$ välfärdsforskning och social rapportering att koncentrera intresset till onda förhållanden, att ägna sig åt vad som kunde kallas eländesbeskrivningar.

Värderingsskillnader i befolkningen ger en rimlig grund för denna fokusering av välfärdens baksida (Johansson 1970). Vi kan skilja oss ganska avsevärt åt $i$ vad vi anser vara ett gott liv. För några kan det avgörande kriteriet vara den materiella standarden, för andra möjligheten att ägna sig år friluftsliv och för ytterligare några att umgås med familj och vänner. Det gör att det inte är möjligt att beskriva "det goda livet" på ett sätt som alla är överens om. Däremot torde det finnas en betydande överensstämmelse om vad som utgör dåliga villkor. Ingen kan finna det önskvärt att vara sjuk, fattig och utan bostad. Därmed kan en social rapportering, som koncentreras till en beskrivning av dåliga villkor, vara värderingsmässigt relativt oproblematisk såtillvida att alla kan instämma $i$ att de tillstånd som beskrivs är just dåliga. Sedan kan det naturligtvis finnas avsevärda skillnader i uppfattningar om varför människor hamnar i sådana tillstånd och vad man eventuellt bör göra åt dem.

Efter den studie av dem med de lägsta lönerna som Sundbom genomförde inom ramen för den första levnadsnivåundersökningen har, som nämnts, studierna ofta snarare avsett ojämlikhet mer än fattigdom, det vill säga att man koncentrerat intresset mer till vad som bedömts vara ett dåligt samhällstillstånd än dåligt individtillstånd. Betoningen av onda förhållanden för samhällsmedborgarna har således varit långt ifrån fullständig.

\section{Social rapportering}

Uppdraget till SOFI att utveckla idén om social rapportering kan sägas ha sammanfattats i två skrifter. I Mot en teori för social rapportering diskuterar Johansson (1979) den teoretiska grunden för en återkommande systematisk beskrivning av tillstånd och förändring av de sociala förhållandena i ett land. Det nya i denna skrift är knappast behandlingen av levnadsnivåns innehåll och avgränsning, här ges främst en systematisk framställning av den tidigare diskussionen, utan snarare att Johansson hävdar en tes om social rapportering som ett element $\mathrm{i}$ den politiska processen - man kan kanske säga att den teori för social rapportering som han utvecklar snarare är politisk än sociologisk.

Ett politiskt beslut kräver en uppfattning om vad man vill uppnå - målet för beslutet - och hur man skall göra för att närma sig målet - de tillgängliga och lämpliga medlen. Men dessutom krävs en kunskap om hur 
det är, det vill säga en beskrivning av nuläget för de samhällsförhållanden man vill förändra. Johansson framhåller att medan politisk teori föreskriver hur man väljer mål och medel - genom politisk diskussion respektive genom vetenskap och rationella överväganden - saknas en uppfattning om hur man fastställer hur det är. Här menar Johansson att det finns en lucka i teorin om demokrati och det är den sociala rapporteringens uppgift att fylla denna lucka. Ofta försöker man, för att få en uppfattning om hur det förhåller sig med något förhållande i samhället, sammanställa personliga erfarenheter, situationer som man hört om och vad massmedia redovisat i den aktuella frågan. Detta kan emellertid förväntas leda till en skev bild, som kommer att domineras av de mest högröstades och resursstarkas erfarenheter. Om beskrivningen av den sociala verkligheten överlåts till en social rapportering som bygger på de bästa socialstatistiska metoderna kan vi hoppas att uppnå att den politiska diskussionen handlar om hur verkligheten skall utvecklas på bästa sätt snarare än vilken den är.

I Välfärd $i$ förändring (Erikson och Åberg 1984) gav en forskargrupp vid SOFI ett svar på frågan om hur den sociala rapporteringen kan tänkas konkretiserad genom att redovisa tillstånd och förändring för levnadsnivåns olika komponenter under perioden 1968 till 1981. För olika indikatorer på de nio komponenterna, och även för mer sammanfattande mått, redovisas och diskuteras genomsnittlig förändring under de tretton åren, genomsnittliga skillnader mellan olika grupper i befolkningen samt eventuella förändringar av dessa genomsnittliga skillnader. De befolkningsgrupper som jämfördes avgränsades med hjälp av de variabler som spelat störst roll i fördelningsdiskussionen - kön, ålder, socialgrupp och ortstyp. De flesta i befolkningen kan troligen identifiera de kategorier som avgränsas på detta sätt - män och kvinnor, olika socialgrupper, äldre, medelålders och yngre samt storstadsbor, stadsbor och landsbygdsbefolkning. Genom att redovisa skillnader mellan sådana grupper, mellan vilka många av de politiska fördelningsstriderna står och har stått, hoppades man kunna ge en beskrivning av utvecklingen som var, och är, så relevant för den politiska diskussionen som möjligt.

I Vardagens villkor väljer Fritzell och Lundberg (1994) en mindre systematisk form för redovisning av den sociala utvecklingen för att i stället kunna ge en mer ingående och djupare beskrivning av förhållandena för specifika grupper och ge kapitelförfattarna friare händer i att utforma sina kapitel beroende på vilka förhållanden de behandlar. På så sett redigerade de vad som nog var en mer läsvärd bok än Välfärd $i$ förändring, men som samtidigt kanske inte lika enkelt ger en sammanfattande bild av den sociala utvecklingen.

Från SCB:s ULF-undersökningar har ett stort antal rapporter om situationen i skilda avseenden som hälsa, boende och inkomster redovisats, ${ }^{16}$ men också mer övergripande beskrivningar (Vogel 1987). Vad som kunde beskrivas som en social rapport, det vill säga en sammanfattande redovisning av individernas välfärd och hur den förändrats levererades av SCB år 1997

16 Se serien Levnadsförhållanden i Sveriges Officiella Statistik. 
(Vogel och Häll 1997). Den byggde på tjugo års ULF-intervjuer och redovisade på ett standardiserat sätt hur olika levnadsförhållanden varierar mellan vissa befolkningsgrupper och över tid. Målsättningen var således i stort sett densamma som den för Välfärd i förändring, men redovisningsformen var något annorlunda.

En brist i den svenska välfärdsforskningen har varit att den $\mathrm{i}$ allt för stor utsträckning betraktat individen utanför sitt sociala sammanhang. Mer information om detta samlades i anslutning till levnadsnivåundersökningen 1991 in genom att man intervjuade chefer eller personalchefer på de arbetsplatser där de intervjuade var anställda. ${ }^{17}$ Resultatet blev inte bara kunskap om arbetsplatsvillkoren för de intervjuade individerna utan också den första undersökningen av ett representativt urval av svenska arbetsplatser (le Grand, Szulkin och Tåhlin 1993). I rapporten tas en rad aspekter på organisationen av arbetsplatserna upp liksom de förutsättningar de ger för individernas utveckling och karriärer, och även en nu så aktuell fråga som arbetsplatsernas betydelse för sjukfrånvaron (Edling 1996).

Att som i många av dessa rapporter redovisa skillnader i olika värderelevanta avseenden - inkomst, arbetsförhållanden, utbildning, hälsa - mellan befolkningsgrupper snarare än som en spridning i befolkningen som helhet, det vill säga att exempelvis redovisa förändringen av inkomstskillna-

17 Intervjuerna genomfördes endast under förutsättning att de intervjuade gav sitt godkännande och i syfte att skydda de intervjuades identitet genomfördes inga intervjuer vid arbetsplatser med färre i tio anställda. derna mellan olika socialgrupper snarare än förändringen av inkomstspridningen $i$ befolkningen, är ett sätt att till någon del komma runt problemet med preferensstyrda val vid jämförelser mellan individer. Om till exempel en pojke efter avslutad grundskola väljer att börja förvärvsarbeta medan en annan väljer att fortsätta på en teoretisk gymnasielinje är det fullt rimligt att tänka sig att det beror på att den första föredrar inkomster nu framför relativt högre inkomster senare i livet, medan den andre har de motsatta preferenserna. Om vi emellertid finner att barn från olika samhällsklasser med ungefär samma intellektuella förutsättningar systematiskt tenderar att välja på skilda sätt efter grundskolan blir antagandet om att ungdomarna väljer fritt utifrån sina preferenser mindre plausibelt. De som argumenterar för att valen främst styrs av preferenser måste i vilket fall ge en rimlig förklaring till varför preferenserna varierar med socialgrupp..$^{18}$ En alternativ förklaring kan i stället bygga på att klassstrukturen innebär sådana skillnader $i$ resurser att valen blir olika även vid samma preferensordning (Se Erikson och Jonsson 1995; Jonsson och Erikson 2000).

Den välfärdsforskning som genomfördes i anslutning till de första levnadsnivåundersökningarna var, delvis beroende på låginkomstutredningens direktiv och på

18 Sådana försök har naturligtvis också gjorts. Hypotesen att barn ur medelklassen i högre utsträckning än arbetarbarn tenderar att acceptera att behovstillfredsställelsen skjuts på framtiden kan sägas vara ett exempel på att försöka förklara beteendeskillnader av angivet slag med hjälp preferensskillnader och strukturellt bestämda personlighetsegenskaper. 
det uppdrag som sedermera gavs till SOFI, i hög utsträckning inriktad mot beskrivning av medborgarnas villkor i skilda avseenden. Över tid har intresset alltmer kommit att förskjutas mot studiet av förändring och av hur olika aspekter av välfärden hänger samman, hur de påverkar varandra och hur de beror av andra förhållanden. Det vill säga att välfärdsforskningen har alltmer kommit att behandla orsaker och processer - varför vissa har det bättre och andra sämre, vad olika typer av arbetsplatser betyder för hälsa och välbefinnande, hur utvecklingen från barndom, över skolgång, till arbete och familj gestaltas för människor med olika socialt ursprung etc. Detta har bland annat manifesterats i en lång rad avhandlingar från SOFI där olika aspekter av människors välfärd belysts djupare, där sociala processer som påverkar välfärden har analyserats och där man sökt förklaringar till välfärdsskillnader mellan olika grupper i befolkningen. ${ }^{19}$

\section{Varthän?}

Hur skall vi då förvänta oss att välfärdsforskningen utvecklas. Som framhölls tidigare är det svårt att sia, men det kanske ändå kan vara värt att diskutera vart aktuella tendenser verkar att peka eller, åtminstone, att ta upp vilken utveckling jag tycker vore önskvärd.

\section{Kopplingmellan komponenter}

För en bättre bild av människors villkor

19 SOFI:s avhandlingsserie finns redovisad på institutets hemsida www.sofi.su.se. och av vad som påverkar dem behöver vi simultant kunna behandla uppgifter som avser olika aspekter av individernas välfärd. I detta avseende fick vi redan i levnadsnivåundersökningen 1968 uppgifter om de skilda komponenterna, men hittills har man knappast hittat något effektivt sätt att redovisa dem samtidigt för att kunna beskriva en eventuell anhopning av problematiska situationer (se det första försöket som Michael Tåhlin och jag gjorde i Välfärd i förändring). För förståelsen av hur olika välfärdskomponenter påverkar varandra behöver vi naturligtvis också uppgifter om dem vid flera tidpunkter.

Frågan hur flera komponenter skall behandlas samtidigt berör det ovan nämnda problemet med att väga samman olika aspekter av människors välfärd till ett sammanfattande mått. Som framhölls går detta inte att göra på ett invändningsfritt sätt. Samtidigt är det uppenbarligen en brist att vi inte på ett enkelt sätt kan uttala oss om fördelningen av välfärd $i$ befolkningen eller om välfärdsutvecklingen som helhet.

En önskan om att kunna ge en lättfattlig sammanfattande bild av välfärdsutvecklingen borde då kanske leda till att man skulle pröva att bortse från omöjligheten att på ett invändningsfritt sätt väga samman levnadsnivåkomponenterna och skapa ett sammanfattande index, exempelvis genom att för varje individ räkna antalet indikatorer där individens värde faller under något gräns eller genom att på något annat sätt väga samman värdena på olika indikatorer. Ett sätt att åtminstone minska ojämförbarhetsproblemet vore att skapa flera sammanfattande index, där vägningen av de olika indexen görs så att de kommer 
att betona skilda problemsfärer. Om sedan flera index ger likartade utfall skulle kanske tolkningsproblemen inte bli särskilt stora, eller annorlunda uttryckt, skulle kanske nästan alla kunna instämma i att välfärdssituationen förbättrades eller försämrades.

Om man utgår från paneldata är det möjligt att studera välfärdsutvecklingen på individnivå och för varje välfärdskomponent beräkna om individens situation har förbättrats, försämrats eller förblivit oförändrad under, säg, det senaste året (eventuellt med någon form av kontroll för åldersfaktorn). Det vore sedan möjligt att exempelvis redovisa andelen individer som inte erfarit några förbättringar av sin situation liksom andelen som inte erfarit några försämringar och likaså andelarna som erhållit förbättringar eller försämringar i flera avseenden.

Inom EU finns ett intresse för att få fram ett mindre antal sociala indikatorer som är gemensamma för hela unionen. I en rapport till EU (Atkinson m.fl. 2002) föreslår en grupp samhällsvetare att länderna i EU skall redovisa sociala indikatorer på tre nivåer, en första med ett litet antal centrala identiska indikatorer, en andra med ytterligare en grupp av identiska indikatorer, vilka dock är något mindre centrala än de i den första gruppen, samt en tredje grupp av indikatorer som är specifika för de enskilda länderna.

Med tillgång till indikatorer av detta slag borde man sedan kunna kräva en snabbare rapportering av välfärdsutvecklingen (se Bokslutskommittén 2000, 195-196). Medan ekonomisk statistik i många fall redovisas med blott någon månads fördröjning, kan det ta år innan observationer av hur välfär- den förändras publiceras. Huruvida denna skillnad indikerar statsmakternas värdering av olika aspekter av samhällsutvecklingen må vara osagt, men den ger helt klart inte medborgarna möjlighet att bedöma den aktuella samhällsutvecklingen som helhet och ta politiska beslut på en sådan grundval.

\section{Sociala sammanhang och arenor}

Att människan inte lever $\mathrm{i}$ isolering är knappast en nyhet, men ändå har välfärdsforskningen $i$ alltför liten utsträckning tagit in information om det sociala sammanhang i vilket individerna framlever sina dagar. Relativt stor möda har lagts ned på att få en bild av familjesituationen och som nämnts har man vid levnadsnivåundersökningarna 1991 och 2000 tagit in uppgifter om arbetsplatserna. Men information om vänkretsar och arbetskamrater har i stort sett saknats och informationen om bostadsområden, skolor med mera har varit mycket bristfällig. En bättre förståelse av exempelvis ungdomars val av utbildning kan mycket väl kräva information om det sociala sammanhang i vilket de befinner sig. Ett första steg mot att i levnadsnivåundersökningarna ge en mer fullständig bild av ungdomars uppväxtsituation kan vara den tidigare nämnda insamlingen av uppgifter från barn och ungdomar i anslutning till föräldraintervjuerna. Information har tagits in inte bara från en av föräldrarna utan också från samtliga syskon i åldrarna 10-18 år.

Att studera individer i sin sociala omgivning kan kräva något andra ansatser än de som beskrivits här - vilket också har prö- 
vats av andra forskare (se t.ex. Björnberg och Bäck-Wiklund 1987 eller Gullestad 1984). Hur än informationen samlas in förefaller det angeläget att i högre utsträckning föra in människors sociala sammanhang i analysen av deras förhållanden.

\section{Kopplingövertid}

Både för en beskrivning av individers välfärd och för en förståelse av variationen mellan individer är det väsentligt att ha information om situationen vid mer än en tidpunkt och helst kontinuerligt över en ganska lång tidsperiod. Både resursers värde och problems svårighet sammanhänger med hur permanenta de är. Det är till exempel välkänt att inkomster varierar ganska påtagligt år från år och möjligheten att utnyttja de tillgängliga ekonomiska resurserna påverkas av i vilken utsträckning individen kan räkna med ett stadigt inflöde av pengar. På motsvarande sätt är det en avsevärd skillnad mellan att råka ut för en kortvarig period av arbetslöshet - kanske i bytet mellan två jobb - och att vara långvarigt arbetslös, liksom mellan att tillfälligt vara sjuk och att ha ett permanent hälsoproblem.

För beskrivningen av välfärdsfördelningen i befolkningen är det alltså angeläget att närmare överväga den tidsperiod som olika indikatorer skall täcka och hur de skall utformas. Bör exempelvis ekonomiska resurser avse genomsnittsinkomsten under de fem senaste åren, hur inkomsterna varierat under dessa år och dessutom kanske inkomstutvecklingen under perioden? Samtidigt som det är angeläget att känna till situationen över en längre period är det rimligtvis viktigt att kunna bedöma det akuta läget, vilket gör att vi dessutom behöver någon indikator som avser detta. Till detta kommer att indikatorerna bör vara lätta att tolka, robusta och någorlunda enkla och billiga att ta fram. Att allt detta blir ett krav på en tulipanaros hindrar inte att det är angeläget att välfärdsbeskrivningar beaktar människors situation under en något längre tidsperiod än den vecka upp till ett år som de nu oftast fäster avseende vid.

Information om situationen vid flera tidpunkter är naturligtvis likaså angelägen för att det skall bli möjligt att beskriva förändring. I många fall är det viktigare att se om situationen förändras till det bättre eller det sämre än att få kunskap om det absoluta läget, detta särskilt som många indikatorer ligger på en skalnivå som gör att ett enskilt värde utan referenspunkt på det hela taget är otolkbart.

Vi behöver också information om människors situation vid flera tidpunkter för att kunna avgöra tidsföljden mellan olika faktorer och därmed öka möjligheten att kunna förstå hur de sociala processerna verkar och hur faktorerna påverkar varandra.

Ett sätt att samla in livshistorieuppgifter som använts runt om i världen under de senaste tjugo åren bygger på att man vid intervjuer ställer frågor om tidigare arbeten och om samboenden, äktenskap och barn. Metoden har bland annat prövats i levnadsnivåundersökningarna och har visat sig kunna bidra till en fördjupad bild av många förhållanden (Se Jonsson och Mills 2001). Den kan dock endast användas avseende förhållanden som man kan anta att män- 
niskor minns väl, det torde t.ex. inte vara möjligt att fråga om sjukdomshistorier och hoppas på tillförlitliga svar.

\section{Ett livsperspektiv}

En djupare förståelse för varför människor drabbas av olika problem kan kräva ett mycket långt tidsperspektiv. Så kan exempelvis sjukdomar i vuxen ålder vara grundade i förhållanden under barndomen eller till och med i fosterlivet. Det pekar mot att man i välfärdsforskningen bör sträva efter att följa enskilda individer över hela livet för att kunna avgöra om, och i så fall hur, situationen i barndomen påverkar framgång i skolan och val av högre utbildning, om och hur ungdomsåren påverkar arbetsliv och yrkeskarriär, hur arbetslivet inverkar på förhållandena efter pensioneringen, etcetera.

Insikten om att utfallet av våra liv beror på ett samspel mellan arv och miljö leder till att vi för att kunna förstå variationen i levnadsförhållanden inte bara behöver information om endera sociala situationer eller genuppsättningar utan om bådadera. Därför bör välfärdsforskningen i framtiden sikta mot att ta in såväl social som biologisk information om enskilda individer som sedan kan följas under lång tid.

I Storbritannien har man sedan 1946 genomfört ett antal så kallade kohortstudier, där man alltifrån från födelsen och allt framgent följt dem som fötts under en viss vecka, och liknande studier har startats i andra länder, bland annat Norge och Danmark. Att i Sverige - och ännu hellre i Europa - följa ett stort urval individer från en tidpunkt så nära konceptionen som möjligt skulle på lång sikt vara av oskattbart värde för välfärdsforskningen. Om sedan uppgifter om barn från nya kohorter insamlades regelbundet, säg vart femte år, skulle värdet bli än större. ${ }^{20}$

Socialvetenskapliga forskningsrådet lade för några år sedan fram ett förslag om ett "olivträdsprojekt'21, inom vilket en eller flera kohorter skulle följas från, om möjligt, konceptionen till obduktionen. Projektet skulle vara ett samarbete mellan forskare från ett stort antal discipliner - medicinare, psykologer, pedagoger, kriminologer, sociologer, ekonomer m.fl. - och bilda ett underlag för en djupare förståelse av hur biologiska förutsättningar, miljöförhållanden och sociala villkor samverkar i formandet av individer och deras livsvillkor. På så sätt skulle vi exempelvis få veta mer om hur de tidiga barnaåren påverkar skolframgång och kriminalitet i tonåren, hur barna- och ungdomsår påverkar arbetsliv och familjebildning och hur hälsan beror på tidigare villkor. Ett genomförande av ett projekt som detta skulle dock kräva stöd från riksdag och regering, ett stöd som vi ännu inte lyckats utverka.

Forskningsrådet för arbetsliv och socialvetenskap och det brittiska Economic and Social Research Council har gemensamt gjort en framstöt i EU om att genomföra en europeisk kohortstudie som, utöver vad som kan göras i en nationell studie, också

20 Det är viktigt att framhålla att en sådan datainsamling måste och kan göras så att inga enskilda individer drabbas eller skadas av att uppgifter om dem lagras i en vetenskaplig databas.

21 Namnet bygger på antagandet att den som planterar en oliv själv aldrig får njuta av dess frukter. 
skulle ge underlag för analyser av hur skilda utformningar av samhälleliga institutioner påverkar människornas liv: Vad betyder skilda former av barntillsyn för barnens sociala och emotionella utveckling? Påverkar skilda sätt att organisera skolan ungdomars kunskaper och senare möjligheter i arbetslivet eller påverkar skilda sätt att organisera sjukvården hälsoutfallet? Hur påverkar arbetsmarknadspolitiken riskerna för arbetslöshet i olika grupper? Låser vissa former av socialpolitik mer än andra in människor i bidragsberoende?

Kohortstudier av detta slag skulle tveklöst skapa underlag för forskning som skulle leda till en bättre förståelse för de sociala processer som påverkar människors välfärd.

\section{Nästa utredning?}

Med 30 till 35 års mellanrum har statsmakterna funnit att samhällsutvecklingen föranlett en önskan om en djupare kunskap om välfärdens nivå och fördelning. De skilda regeringarna har haft skilda skäl till varför de funnit det vara angeläget med en närmare belysning av de sociala förhållandena. Vad än regeringen kommer att fråga efter år 2030 vet vi att svaren kommer att bli mer uttömmande och tillförlitliga om statsmakterna ger stöd till fortsatt välfärdsforskning och redan nu stödjer en regelmässig insamling av uppgifter om enskilda individers villkor över livet.

Flera personer - Erland Bergman, Johan Fritzell, Sten Johansson, Janne Jonsson, Olle Lundberg, Michael Tåhlin samt övriga författare i detta tidskriftsnummer och av dem särskilt Björn Halleröd och Margareta Bäck-Wiklund - har gett mig konstruktiva kommentarer på ett tidigare utkast, vilket här tacksamt noteras.

\section{Referenser}

Allardt, Erik (1975): Att ha, att älska, att vara. Lund: Argos.

Andrews, Frank, M. red. (1986): Research on the Quality of Life. Ann Arbor: The University of Michigan.

Arbetsgruppen för låginkomstfrågor (1971): Kompendium om låginkomstutredningen. Stockholm: DS In 1971:16.

Atkinson, Anthony, B. (1975): The Economics of Inequality. Oxford: Clarendon Press (Andra upplagan 1983).

Atkinson Tony, Bea Cantillon, Eric Marlier och Brian Nolan (2002): Social Indicators: The EU and Social Inclusion. Oxford University Press.

Bauer, Raymond. A. red. (1966): Social Indicators. Cambridge: MIT Press;

Befolkningskommissionen (1938a): Slutbetänkande. SOU 1938:57

Befolkningskommissionen (1938b): Betänkande med vissa demografiska utredningar. SOU 1938:24

Bergqvist, Christina och Anita Nyberg (2001): "Den svenska barnomsorgsmodellen - kontinuitet och förändring under 1990-talet«, SOU 2001:52.

Björklund, Anders och Karl-Göran Mäler, red. 
(1991): Välfärd och välfärdsmätning, Ekonomiska Rådet, Stockholm.

Björnberg, Ulla och Margareta Bäck-Wiklund (1987): Vardagslivets organisering i familj och närsamhälle. Göteborg: Daidalos.

Central Statistical Office (1970): Social Trends. London: Her Majesty's Stationary Office.

Campbell, Angus, Philip E. Converse och Willard L. Rogers (1976): The Quality of American Life: Perceptions, Evaluations and Satisfactions. New York: Russell Sage Foundation.

Coleman, James (1971): Resources for Social Change. New York: Wiley.

Edling, Christofer (1996): "Arbetsorganisation och sjukfrånvaro» i Le Grand, Szulkin och Tåhlin 1993.

Erikson, Robert och Rune Åberg red. (1984): Välfärd i förändring: Levnadsvillkor i Sverige 1968 -1981. Stockholm: Prisma.

Erikson Robert och Jan O. Jonsson, eds. (1996): Can Education be Equalized? The Swedish Case in Comparative Perspective. Boulder, Col.: Westview Press.

Erikson Robert och Hannu Uusitalo (1987): »The Scandinavian Approach to Welfare Research", i R. Erikson m. fl. The Scandinavian Model: Welfare States and Welfare Research. Armonk, New York: M.E. Sharpe.

Fritzell, Johan (1991): Inte av marknaden allena: Inkomstfördelningen $i$ Sverige. Stockholm: Institutet för social forskning.

Fritzell, Johan och Olle Lundberg, red. (1994): Vardagens Villkor. Stockholm: Brombergs.

Fritzell, Johan och Olle Lundberg (2000): Välfärd, ofärd och ojämlikhet. Kommittén Välfärdsbokslut/SOU 2000:41.

Glatzer, Wolfgang och Wolfgang Zapf red. (1984): Lebensqualität in der Bundesrepublik: Objektive Lebensbedingungen und subjektives Wohlbefinden. Frankfurt: Campus.

le Grand, Carl, Ryszard Szulkin och Michael Tåhlin (1993; 2:a uppl. 1996): Sveriges arbetsplatser- Organisation, personalutveckling, styrning. Stockholm: SNS förlag.

Gullestad, Marianne (1984): Kitchen Table Society. Oslo: Universitetsforlaget
Gustafsson, Björn (1984): En bok om fattigdom. Lund: Studentlitteratur.

Halleröd, Björn (1991): Den svenska fattigdomen : en studie av fattigdom och socialbidragstagande. Umeå: Umeå univ., Sociologiska institutionen

Halleröd, Björn (1994): Poverty in Sweden : a new approach to the direct measurement of consensual poverty. Umeå: Umeå univ., Sociologiska institutionen

Halleröd, Björn (1999): Fattigdom i Sverige : rapport från arbetsgruppen för ekonomisk trygghet till Nationella folkhälsokommittén. Stockholm : Nationella folkhälsokommittén.

Hansen, Erik Jörgen (1986): Danskernes levekår - 1986 sammenholdt med 1976. Köpenhamn: Hans Reitzels forlag.

Holmberg, Sören- och Mikael Gilljam (1987): Väl jare och val i Sverige. Stockholm: Bonniers.

Inglehart, Roland och Jacques-Rene Rabier (1986): "Aspirations Adapt to Situations - But Why Are the Belgians So Much Happier Than the French' i Andrews red.

Johansson, Sten (1970): Om levnadsnivåundersökningen. Stockholm: Allmänna Förlaget.

Johansson, Sten (1979): Mot en teori för social rapportering. Stockholm: Institutet för social forskning.

Jonsson, Jan O. och Robert Erikson (2000): "Understanding Educational Inequality: The Swedish Experience', L'Année Sociologique Vol. 50, 2000, pp 345-382.

Jonsson, Jan O., Viveca Östberg med Marie Evertsson och Sara Brolin Låftman (2001): Barns och ungdomars välfärd. SOU 2001:58.

Jonsson, Jan O. och Colin Mills, red. (2001): Cradle to Grave: Life-course change in modern Sweden. Durham: Sociologypress.

Kommittén Välfärdsbokslut (2001): Välfärdsbokslut för 1990-talet. SOU 2001:79.

Levekårsundersökelsen (1976): Slutrapport. Oslo: NOU 1976:28

Låginkomstutredningen (1970): Svenska folkets inkomster. SOU 1970:34.

Låginkomstutredningen (1971): Svenska folkets köpkraft. SOU 1971:39.

Mack, Joanna och Stewart Lansley (1985): Poor

Robert Erikson: Svensk välfärdsforskning 
Britain. Hemel Hempstead: Georg Allen and Unwin.

Myrdal Alva och Gunnar Myrdal (1934) Kris i befolkningsfrågan. Stockholm: Bonniers.

Nordiska Rådet (1983): Levnadsnivå och ojämlikhet $i$ Norden. Göteborg.

Orshansky, Mollie (1969): „How Poverty is Measured', Monthly Labor Review, Vol. 92.

van Praag, Bernhard, S. M. (1968): Individual Welfare Functions and Consumer Behaviour. Amsterdam: North-Holland.

Ringen, Stein (1987): The Possibility of Politics. Oxford: Clarendon Press.

Rowntree, B. Seebohm (1901): Poverty: A Study of Town Life. London: MacMillan.

Segerstedt, Torgny T. och Agne Lundquist (1952/ 1955): Människan i industrisamhället, I och II. Stockholm: Studieförbundet Näringsliv och Samhälle.

Sen, Amartya (1984): "Well-being, Agency and Freedom, The Dewey Lectures 1984'. The Journal of Philosophy, vol 84:2.

Sen, Amartya (1985): Commodities and Capabilities. Amsterdam: North-Holland.

Sen, Amartya (1992): Inequality Reexamined. Cambridge, Mass: Harvard University Press.

Statens offentliga utredningar (1970): Svenska folkets inkomster. SOU 1970:34.

Statens offentliga utredningar (1971): Svenska folkets köpkraft. SOU 1971:39.

Sundbom, Lars (1970): De extremt lågavlönade. Stockholm: Allmänna förlaget.

Sundbärg, Gustav (1913): Emigrationsutredningen. Betänkande i utvandringsfrågan och därmed sammanhängande spörsmål / jämlikt kungl. brefvet den 30 januari 1907 afgifvet af Gustav Sundbärg. Stockholm : Nordiska bokh.

Townsend, Peter (1979): Poverty in the United Kingdom. Harmondsworth: Penguin.

U.S. Department of Health, Education and Welfare (1969): Toward a Social Report. Washington D.C.

Vogel, Joachim (1987): Det svenska klassamhället. Stockholm: Statistiska Centralbyrån.

Vogel Joachim och Lars Häll, red. (1997): Välfärd och ojämlikhet i ett 20-årsperspektiv. Stockholm: SCB

Zapf, Wolfgang (1977): Lebensbedingungen in der Bundesrepublik, Sozialer Wandel und Wohlfartsentwicklung. Frankfurt: Campus

Åberg, Rune, red. (1990): Industrisamhälle $i$ omvandling: människor, arbete och socialt liv $i$ en svensk industristad frän femtiotal till aittiotal. Stockholm: Carlsson 


\section{Summary \\ Welfare research in Sweden}

Royal and later Governmental commissions have been important vehicles for the development of empirical studies of living conditions in Sweden during the whole of the twentieth century, from the Commission on Emigration at the start of the century, via the one on low fertility in the 1930s to the Welfare Commission writing its reports at the end of the century. However, the most important inquiry for Swedish welfare research was the Low Income Commission, established in 1965, as it assigned a group of sociologist led by Sten Johansson to make a survey of the level of living in the nation.

Level of living was defined in terms of command over resources and measured in nine different dimensions. The research that followed the level of living study was characterized by a quantitative approach on the basis of large surveys, by concentrating on actual living conditions rather than on life satisfaction, by using a multidimensional concept of welfare, by more attention to inequality than to poverty, while still emphasizing bad conditions. The research started as a response to political demands for information, but developed over time towards "blue skies" research, where the questions emanate inside science and in the minds of the researchers.

The agenda for continued welfare research includes a demand for better ways of combining several indicators to give multidimensional descriptions and perhaps in this way to reach summary measures of the condition and development of individual welfare as well as aggregate measures for a nation. Welfare research in the future should furthermore take more notice than hitherto of the social environment of the individual, should even more than now follow individuals over time and possibly over the whole life span. In this way we would obtain much better knowledge of the determinants of social problems and living conditions in general. 